\title{
ARTIG0S
}

\section{A INTERPRETAÇÃO CRISTÃ DA HISTÓRIA (V) (*).}

\section{(Continuação)}

\section{IV. - AS LEIS DA HISTóRIA.}

\section{C. - LEIS HISTÓRICAS.}

\section{1. - A ordem divina e as leis históricas.}

Idéias como as de um modêlo histórico universal ou de uma ordem divina na História tem sido consideradas com grande desconfiança por muitos estudiosos da História. Têm elas tal amplitude a ponto de parecer que só uma mente divina, que tivesse uma visão total da História, poderia ser capaz de verificar sua veracidade. Inversamente, estudos recentes revelaram grande número de regularidades verificáveis no processo histórico. Elas são, entretanto, muitas vêzes consideradas como sendo apenas de caráter estatístico. Mas quando relacionadas com a idéia de uma ordem divina da História, e assim encaradas sob uma perspectiva teleológica, aparecem sob nova luz. Não é simplesmente por acaso que elas são o que são. Antes ocorrem com uma necessidade que provém do fato que uma ordem divina opera no campo histórico. Mesmo que algumas delas possam ser formuladas em têrmos psicológicos ou sociológicos, sua necessidade não decorre da natureza humana ou das condições terrenas, mas sim do fato de que é por causa de Deus que o homem está destinado a viver uma existência histórica. Não haveria nenhuma razão, de um ponto de vista puramente sociológico ou biológico, pela qual os desenvolvimentos históricos deveriam seguir as linhas que efetivamente seguem. Inversamente, quando interpretados como vários aspectos da operação da justiça divina na História, adquirem aquelas regularidades o caráter de leis. Tal como as leis da natureza apresentam elas validez e necessidade universais. Ainda que seja necessária uma

\footnotetext{
(*). - Este é o quinto artigo duma série de palestras proferidas pelo Prof. Otto A. Piper no Salão Nobre da Faculdede de Filosofia, Ciências e Letras da Universidade de São Paulo em agôsto de 1953. Texto em inglês traduzido por Percy Fávero Schützer (Nota da Redação).
} 
visão compreensiva para notar a operação de uma justiça retributiva na História da humanidade, aquelas leis operam na experiência histórica de cada um. Contudo, a não ser pelos cristãos, são elas experimentadas como meras necessidades. $O$ propósito a que servem é manifesto sòmente àquêles que têm consciência da ordem divina de justiça na História. Razões práticas aconselham-nos a agrupar essa lei de acôrdo com os principais aspectos do campo histórico. Vamos dispô-las nos seguintes grupos:

i) Modos da atividade histórica.

ii) Modelos do processo histórico.

iii) O objetivo da História.

iv) Resultados da História.

\section{L Leis básicas.}

i). - Relativas aos Modos de Atividade Histórica.

a). - Fadiga.

Segundo a concepção bíblica o homem é um pecador, quer dizer, um ser que tenta constantemente afirmar-se contra Deus è que vive como se Deus não existisse e o homem fôsse o senhor exclusivo de seu destino. Como resultado desta rebelião a vida do homem está sob a maldição divina que proclama "no suor de teu rosto comerás teu pão" e "maldita é a terra por causa de ti, com fadiga comerás dela todos os dias de tua vida" (Gên. 3:19 e 17). Os fatos da História não confirmam a esperança utópica subjacente à crença no Progresso, por exemplo, como se as condições históricas estivessem melhorando automàticamente dia a dia. Ao contrário, o homem vive num mundo que por sua própria natureza não é subserviente a seus planos. A vida histórica requer não sòmente esfôrço da parte do homem mas tem êle também que vencer a resistência passiva - e muitas vêzes ativa - que uma natureza relutante contrapõe a suas aspirações.

Não obstante a "Ciência cristã", o mal não é mera ilusão de nossa mente. Antes encontramos fôrças do mal por tôda a parte ao nosso redor como, por exemplo, a pobreza, a debilidade, o antagonismo, o engano, a morte, e o homem tem que combatê-1as constantemente se quiser impor sua vontade sôbre o meio. A atividade histórica assemelha-se mais à do soldado que à do artista. A História não avança por si, mas é antes impelida para a frente por "sangue, suor e lágrimas". Ainda que em sua graça Deus nos ofereça oportunidade de avançar na História, é ùnicamente através do esfôrço que uma oportunidade pode ser transformada em su- 
cesso. Assim de nada servirá por meio de uma acrobacia dialética chamar de bens os males históricos, como fazem Hegel e outros filósofos. Se alguma coisa é realizada na História é por causa do árduo trabalho do homem e não em virtude da vexante presença de males.

Por natureza o homem tem aversão à fadiga e evita-a. Não é supreendente, portanto, que a História seja rica de exemplos nos quais um grupo histórico procura deslocar o fardo para ombros mais fracos ou, pelo menos, tenta dividir êsse fardo de tal maneira que os que estão no poder reservam para si a porção que promete a satisfação maior. Nos grupos mais primitivos, por exemplo, os homens dedicam-se à caça enquanto que o trabalho servil do campo, da horta e do lar é deixado para as mulheres; em estados mais avançados o grupo ou classe superior está pronto a tomar sôbre si a tarefa de administração, deixando para seus subordinados as tarefas manuais e mecânicas. Sendo assim, haverá sempre um coitado, uma classe inferior dentro de uma nação por democrática que seja sua constituição. De modo análogo, na vida internacional as nações poderosas usarão sempre sua superioridade política, econômica ou militar para explorar outras, não obstante a existência das Nações Unidas, de Conselhos de Tutela e de pactos hemisféricos. Mas tôdas as unidades históricas foram postas sob a lei da fadiga. Tentando evitar canseiras as nações ou os grupos se enfraquecem. "Engordam", tornam-se balofos, corruptos. A História também nos fornece ampla evidência do declínio gradual de uma nação que transfere o combate efetivo numa guerra a exércitos mercenários ou aos soldados de seus aliados, contentando-se a nação poderosa em fornecer os implementos de guerra ou em financiar os armamentos dos aliados.

A mesma conseqüência virá quando os que não podem lançar sôbre outros o fardo, tentam evitar a necessidade da fadiga mediante atividades e ações que dêem a aparência de trabalho. Mencionemos, por exemplo, a tendência generalizada de nossa época de organizar conferências, promover debates e aprovar resoluções em vez de fazer alguma coisa àcêrca do assunto, ou de pretender resolver problemas apenas pela criação de novas organizações administrativas ou de investigação. Anàlogamente, a tendência das massas modernas de se divertir com as atividades de outros, por exemplo, assistindo jogos esportivos ou filmes de cinema ou espetáculos de televisão enquanto permanecem passivas é òbviamente um sintoma do desêjo de evitar a canseira da vida histórica. Tal tendência acabará, todavia, por levar ou a um govêrno ditatorial quando o povo evitar esfôrço implícito no contrôle democrático ou então à desintegração nacional, quando os cidadãos não mais se preocuparem com o fato de seu país estar ou não desempenhando um papel na História. 
Esfôrço e fadiga são os pré-requisitos de tôda a existência histórica. Um grupo histórico, porém, que deseje tornar-se grande em lugar de apenas se contentar com o status quo, precisa dar um passo além. Sòmente o sacrifício é a base da grandeza. A vida de Jesus, que estabeleceu o exemplo de uma vida humana verdadeiramente grande, foi uma vida de sacrifício. Através dêle tornou-se claro que o trabalhador esforçado e o guerreiro, por efetivos que êles sejam na História, não representam o tipo supremo de atividade histórica. A superior grandeza do sacrifício manifesta a razão fundamental da lei da fadiga. Tudo que é valioso na vida tem um preço que o homem tem de pagar. Ainda que as coisas boas da vida possam lhe ser oferecidas sem esfôrço de sua parte, mediante uma herança, por exemplo, ou por acaso, êle tem, todavia, que se esforçar para conservá-las como sua propriedade. Além disso os grandes valores da vida não podem ser alcançados sem o sacrifício dos menores. O rápido sucesso dos regimes totalitários modernos, por exemplo, explica-se fàcilmente pelo fato de que seus guias são capazes de persuadir tôda uma nação a sacrificar a felicidade individual, a segurança e a prosperidade em favor do progresso de sua causa. Se a despeito dos sacrifícios êstes sistemas fracassam finalmente, sua queda provém de sua crença errônea de que o poder político é o supremo valor da História. Mas é igualmente óbvio que o poder militar superior, embora suficiente para derrotar um regime político, não conseguirá destruir a crença que torna possíveis tais sacrifícios. Apesar dos nazistas, por exemplo, terem sido batidos temporàriamente no campo de batalha, a Europa e o mundo tem ainda que se livrar do espírito do fascismo. Se a ameaça dos movimentos totalitários - e o fascismo é tão perigoso quanto o comunismo - deve ser vencida é necessário ter uma visão de valores mais altos que os dêles e a disposição para maiores sacrifícios que os por êles efetuados.

b). - Ințegração.

Sem discutir aqui a participação das grandes personalidades, de um lado, e da coletividade, de outro, na causação de realizações na Historia, esta certamente nos ensina que empreendimento algum terá conseqüências históricas, isto é, afetará decisivamente o campo histórico, a menos que seus executores ajam como membros de uma coletividade e não por si mesmos. Isto se aplica não apenas ao individualista estrito, mas também aos que querem ser benfeitores ou beneficiários dos recursos do grupo histórico, querendo porém guardar sua independência. Quanto menos consideração fôr dispensada ao campo histórico como um todo, tanto menores serão as possibilidades de indivíduos grandes ou poderosos; 
ou de grupos, nele se afirmarem de modo duradouro ou dêle prosperar em sua totalidade. Não existe nada estático na História. O campo histórico constantemente varia devido a deslocamentos intrínsecos de seus centros de energia e a novas influências externas. Assim o campo faz sempre novas exigências à lealdade de seus membros. Significa isto que a correlação existente entre seus membros, por exemplo, o estoque racial comum ou o habitat comum, ou um passado comum, devem sempre ser transformados de novo em cooperação e coordenação. Os vínculos da tradição e das circunstâncias externas, pelos quais um campo histórico mantém-se unido, devem ser elevados a uma integração de seus membros, consciente e voluntàriamente aceita, para evitar que o grupo se desintegre. A operação dêste princípio é bastante óbvia na formação de nações em países coloniais como, por exemplo, nas Américas, onde a unidade artificial existente entre súditos de um soberano distante foi substituída pela auto-determinação nacional. Os dois tipos mais notáveis dêste princípio são a Lei da Interdependência e a Lei da Solidariedade.

\section{a). - Lei da Interdependência.}

Um dos característicos básicos das coisas terrenas é a indissolúvel correlação de espécie e indivíduo, ou de unidade e diversidade. Não pode haver nenhuma dúvida de que tôda a gente da terra pertença à raça humana, isto é, que tenham características em comum que as diferencia de todos os animais. Foi um engano fatal, porém, a interpretação dada a êste fato tanto pelos antigos filósofos gregos como pelos racionalistas modernos como implicando que os característicos peculiares de indivíduos humanos ou grupos históricos eram meros incidentes e nada tinham que ver com a natureza humana. Em conseqüência as pessoas deviam ser tratadas como se essas diferenças não existissem. Mas é o oposto que é verdadeiro. Somos incapazes de agir de um modo verdadeiramente humano a menos que nos disponhamos a tomar aquelas peculiaridades a sério, quer dizer, respeitando-as em cada indivíduo e agindo com isso em mente. A vida histórica é a coexistência de grupos e de indivíduos que são diferentes. Por isso nenhum grupo histórico será capaz de agir com sucesso a não ser que seus membros, cada um de acôrdo com suas habilidades peculiares, tome parte na vida da coletividade. Neste sentido a democracia é um aspecto constitutivo da vida histórica. E' também óbvio, contudo, que assim entendida, a democracia é um conceito funcional. Não esta ligada, por exemplo, a um sistema parlamentar representativo. O que importa mais do que qualquer outra coisa na vida política é a participação real de todos no processo de govêrno, e não, como Platão, Aristóteles e seus seguidores pensaram, a forma de govêrno. 
A lei da interdependência se aplica também à vida internacional. Uma nação auto-suficiente ou uma "cultura nacional" contida em si mesma é coisa que não existe. A cultura dará sempre expressão às energias criadoras de um grupo histórico, e assim será sempre nacional. Mas ela não será cultura a menos que aquelas fôrças criadoras operem conscientes da vida cultural de outras nações e em cooperação com essa vida. Tal receptividade e cooperação não está ligada a organizações internacionais de governos tais como as Nações Unidas ou a UNESCO. O que importa é o intercâmbio e cooperação reais de indivíduos e instituições nacionais, a receptividade e o respeito pelas peculiaridades e pelos dons específicos de outras nações e grupos, e a presteza em deixar-lhes participar de nossas realizações e atividades. $E^{\prime}$ isto verdade em tôdas as esferas da vida histórica e não apenas no domínio da cultura. O assim chamado realismo que faz com que unidades históricas se tenham em tão alta conta que pretendam não necessitar das demais, e, por sua vez, guardar para si tudo o que têm, está longe da sabedoria. Fechando-nos, empobrecemo-nos.

A lei da interdependência implica que os poderosos não prosperarão a longo têrmo, exceto se tomarem em consideração os interêsses dos fracos e pequeninos. Uma vez que o poder histórico é poder sôbre um campo, êle só pode ser exercido dentro dêsse campo. Govêrno por contrôle remoto não pode perdurar. Quando os poderosos deixam de cooperar com os membros do campo ou desprezam seus interêsses, criam o desassossêgo e a instabilidade, que trazem como conseqüência a diminuição dos frutos de seu poder. E operam por fim a dissolução do campo e com isto a destruição da própria base do poder que detém. Assim, por exemplo, a exploração econômica conduz à revolução, a supremacia racial e a discriminação ao ódio, e a conquista e o imperialismo à rebelião das nações dominadas.

\section{$\beta$ ). L Lei da Solidariedade.}

A consideração pelos interêsses alheios, além de ser uma exigência moral, é também simples sabedoria política e histórica. Mas o exemplo de Cristo mostra e a experiência confirma que as recompensas da atividade histórica crescem quando uma atitude de solidariedade toma o lugar da mera consideração pelos outros. Em lugar de apenas tentar viver bem com os outros e tanto quanto possível não os ferir, vale a pena considerarmo-nos orgânicamente ligados a êles.

As gerações passadas, por exemplo, não são apenas aquelas que na ordem cronológica viveram antes de nós. São as que moldaram o campo histórico no qual vivemos. A atividade histórica 
pressupõe uma herança para ser trabalhada. Ela nunca parte do nada. E' por esta razão que o cultivo da tradição é tão importante para a prosperidade de um campo histórico. Atribuindo à tradição uma posição central os membros de um grupo histórico reconhecem o fato que os recursos e as energias presentes do grupo foram criadas pelos antepassados. E' em virtude de nossa solidariedade com as gerações precedentes que as reminiscências do passado são tão valiosas. Elas nos habilitam a melhor compreender nosso lugar específico na História e agir com a consciência de nossos recursos e possibilidades. Tanto os feitos como os desatinos de nossos antepassados apontam para aspectos de nosso caráter nacional. Pode ser difícil para um grupo histórico tomar suas decisões por gratidão pelas gerações precedentes. Mas o fato do culto dos antepassados, por exemplo, é indício da compreensão generalizada de que ações praticadas em completo desrespeito pelas intenções das gerações precedentes acabarão em desastre para o campo histórico. Este fato explica, entre outras coisas, as difíceis decisões com que se defrontam as nações da Ásia e da África ao sentirem o impacto desafiador do mundo ocidental.

E' impossível para um corpo histórico agir com eficácia a menos que o faça de acôrdo com a natureza de seu campo histórico, e para tal fim são indispensáveis as tradições. $O$ estudo de instituições estrangeiras, por exemplo, pode atuar como um estímulo para iniciar reformas nas instituições de uma nação. Mas a imitação de instituições estrangeiras não produzirá resultados. As reformas devem se basear nas tradições de um grupo. E' portanto absurdo que os conquistadores tentem impor sua civilização ou sua lei a uma nação conquistada, a menos que a nação voluntàriamente a assimile em sua vida nacional.

A geração presente deve também estar preparada para assumir a responsabilidade moral por suas condições presentes. Ao usarmos nossa herança histórica não podemos negar os aspectos desagradáveis ou injustos que o passado nos legou, como se fôssem a falta do regime precedente ou de gerações passadas apenas, e os vivos nada tivessem a ver com êles. Por mais crítica que a nova geração seja de seus pais, deve ela aceitar as condições históricas como um todo indivisível. Ela não teria nem mesmo a capacidade de criticar o passado da maneira em que o faz se não fôssem as capacidades e a compreensão que herdaram dos antepassados. Hitler, por exemplo, revelou pensamento não histórico quando, em seus esforços, para resolver o problema judeu, agiu como se êle e seus contemporâneos não fôssem responsáveis pelo fato de estarem os judeus vivendo entre êles. Deixou êle de considerar que seus antepassados alemães haviam criado para os judeus as condições que finalmente resultaram nas inegáveis friç̧ões e 
tensões do século $\mathrm{XX}$. Igualmente errada é a tentativa dos brancos nos Estados Unidos ou na África do Sul de resolver o problema dos pretos mediante radical segregação, isto é, como se ambas as raças nada tivessem que ver uma com a outra. Pois, na realidade, foram seus antepassados que empregaram os escravos a fim de prosperar em sua vida econômica.

Em virtude da continuidade temporal do campo histórico há também uma solidariedade com a geração vindoura. Os descedentes ainda por nascer serão prejudicados se a geração presente utilizar seus recursos e energias desprezando os interêsses $e$ as necessidades daqueles que a seguirão. Nossa moderna economia de desperdício, por exemplo, poderá deixar nossos descendentes penosamente empobrecidos, se, por ambição ou descuido, derrubarmos nossas extensas florestas ou ocasionarmos a erosão dc solo que carrega o humus fértil para o fundo do oceano. Anàlogamente, se uma nação se entrega ao vício, à embriaguez e uso de narcóticos, os filhos e netos pagarão em têrmos de saúde física, moral e mental debilitada. Ações contrárias à lei de solidariedade não sòmente desfarão as realizações pelas quais outros labutaram e sofreram mas também acabarão por enfraquecer o campo histórico como um todo.

ii). - Leis relativas ao Processo da vida histórica.

a). - Oportunidade.

O "Pregador" do Velho Testamento nos lembra de que "tudo tem o seu tempo determinado, e há tempo para todo o propósito debaixo do céu" (Ec1. 3:1), e o sábio antigo apresenta uma lista longa das aplicações de tal princípio (Ecl. 3:2-8). O tempo não é um vácuo em que se movem as coisas e as pessoas. Uma vez que Deus fêz tôdas as coisas para um fim determinado, o processo do tempo é um fator positivo que contribui para que aquêle fim seja alcançado. Uma indicação sôbre a natureza do tempo encontra-se no fato que cada unidade histórica tem a oportunidade de vencer os obstáculos em seu caminho para seu objetivo e de se apropriar dos recursos para isso necessários. Assim como a semente plantada não germinará até que chegue a estação, assim também o processo histórico tem suas "estações". Mudanças decisivas na viḍa nacional ou na história de um grupo qualquer não dependem dos desejos ou das intenções dos que tem a responsabilidade de operá-las. São vãos tođos os esforços antes do momento oportuno. Há anos, e algumas vêzes o período de tôda uma geração, em que nada ocorre de decisivo, e não por falta de vontade ou de visão do povo em apreço mas antes por falta 
de oportunidade. Por isso o estadista tem de aprender a aguardar a ocasião própria e a esperar pacientemente a chegada do momento para sua ação. Outras vêzes, condições nacionais e internacionais que durante longo tempo permaneceram rígidas tornam-se sùbitamente flexíveis. Entretanto tais condições perduram apenas por um pouco, e como a oportunidade não volta, o estadista deve estar pronto para aproveitá-la imediatamente. $O$ modo pelo qual êle se serve da situação oportuna determinará o futuro de seu país, e assim manifestará a verdadeira estatura do estadista.

$E^{\prime}$ por isso que na vida histórica o primeiro passo é tão decisivo. Unnicamente em nossas reações imediatas a um momento crítico é que somos livres verdadeiramente no campo da atividade histórica. Tudo o que segue é determinado por elas. Não há possibilidade de corrigir o êrro de uma falsa apreciação de um momento oportuno ou de uma errônea reação diante dêle.

$E^{\prime}$ óbvio que o mundo ocidental, por exemplu, vive presentemente em um período histórico no qual sua oportunidade passada foi perdida sem que uma nova se tenha apresentado. Desde a conferência de Teerã em 1944, ou talvez desde Munique em 1938 tudo se deu com inelutável necessidade. Entretanto, uma nova opcrtunidade poderá surgir para uma das grandes potências. E' por esta razão que é perigoso planejar o futuro exclusivamente do ponto de vista da segurança, isto é, em têrmos de uma situação imutável. Sem o máximo de flexibilidade uma nova oportunidade poderá mais uma vez se perder.

Não é possivel prever quando, nem em que circunstâncias, uma oportunidade surgirá; esta, porém, não é um mero golpe da sorte. E' fora de dúvida que lances favoráveis ou adversos ocorrem na História, como, por exemplo, uma traição pela qual os planos estratégicos de um exército se tornam conhecidos do inimigo, ou então catástrofes tais como a morte súbita de um grande estadista que priva temporàriamente uma nação de seu líder. Mas por si mesmos tais caprichos do acaso não trazem conseqüências históricas de longo alcance, porque não criam uma situação flexível. A oportunidade histórica é sobretudo um acontecimento na história espiritual. As oportunidade oferecidas em tais momentos habilitam um grupo a apreender qual a sua importância para o destino da raça. São portanto primàriamente oportunidades de crescimento em valor, e nunca meras oportunidades de expansão quantitativa. Se o desafio resultasse de circunstâncias históricas apenas, a natureza da crise poderia ser definida em têrmos quantitativos, pois seu objetivo seria a prosperidade ou o domínio do grupo em apreço ou do oponente. Por não terem apreendido o caráter espiritual da oportunidade histórica, alguns filósofos foram levados a advogar a renúncia à vida histórica e à vida pública. $\mathrm{O}$ ob- 
jetivo da oportunidade é, porém, uma vida verdadeiramente humana. Isto se pode ver no fato que a oportunidade traz consigo a possibilidade de erros, isto é, da escôlha de meios falsos para ir a seu encôntro, e também a tentação de usá-la para falsos fins.

\section{b). - Tipos de Vida em Comum.}

Desde o tempo de J. J. Rousseau fizeram-se tentativas de interpretar a História como o resultado da agregação de indivíduoos inicialmente independentes e auto-suficientes. Não há indicação alguma, contudo, de que tenha existido êsse estado "pré-histórico" da vida humana. Os advogados dessa hipótese terão grande dificuldade para explicar porque os homens, quando se unem para a ação coletiva, formam regularmente e por tôda parte o mesmo tipo de vida em comum. Onde quer que encontremos o homem, seja na remota Antigüidade seja em nossos dias, êle vive em familia, tem uma ordem política, mantém relações econômicas, pratica o intercâmbio cultural e cultua em comunidades religiosas. E' óbvio que o homem não só é incapaz de ser homem a não ser que viva històricamente, isto é, unido a outros para a busca em comum de um objetivo futuro, como também é incapaz de libertar-se da necessidade de buscar os objetivos que sua natureza the impõe. Em sua busca êle tem que viver em tipos definidos de vida em comum. Os teólogos luteranos chamam-nos de "ordens da criação" indicando assim que êles resultam necessàriamente do fato que a natureza humana é imutável. A existência de indivíduos fora dessa união constitui exceção raríssima e não a regra, e isto terá sempre efeito prejudicial sôbre suas vidas. Temos exemplo disto nos efeitos degeneradores do isolamento sôbre as vidas dos índios proscritos que vagavam pela Sierra Nevada, notados pelos primeiros colonizadores.

O estudo da História nos ensina que há muitos modos diferentes de realizar um certo tipo de vida em comum. Conhecemos, por exemplo, a família patriarcal e a matriarcal, a família "compreensiva" da China e a familia moderna, de duas gerações, do mundo ocidental, a família polígama e a monógoma, a exogâmica e a endogâmica, etc. Mas tôdas estas diferentes formas de vida em comum são famílias. Cada uma se agrupa em tôrno da relação sexual do homem com a mulher e de cuidado da prole e tôdas servem ao mesmo propósito de preservar e proteger essas relações. Notamos igualmente formas quase inumeráveis de organização política. Mas tôdas têm como centro o fato da soberania, e tôdas habilitam a comunidade a ter coesão e a buscar os fins comuns baseada na soberania e na obediência. O mesmo é verdade nas relações concernentes à produção e intercâmbio de bens econômicos, à aquisição 
e transmissão da verdade e do conhecimento ou à pratica em comum do culto.

As formas de realização dêstes tipos de vida em comum estão constantemente sujeitas a mudanças continuando porém a servir - mesmo objetivo. Diante dêste fato, é evidente que a forma específica que tal relação assumiu em um dado ponto da História não é determinada exclusivamente pela escôlha do grupo e pelas circunstâncias, mas também pelo fim transcedente e objetivo que ela serve. E' óbvio que há no homem a vontade de fazer de cada forma da vida em comum o instrumento mais apropriado para alcançar seu fim específico. Assim, por exemplo, a história do casamento mostra como sua forma é influenciada por fatôres econômicos e pelo sistema legal da unidade histórica. Mas a família como instituição social não é criada por êstes fatôres. Antes, ela se mantém unida em virtude do desêjo de permanência na relaçãò sexual e do cuidado pelos filhos. Tal objetivo não mudará a despeito das várias concepções da vida humana e do lugar ocupado pelas relações de sexo $\mathrm{e}$ de sangue que modificam a forma do casamento. Notamos, todavia, na História a tendência de aperfeiçoar aquelas formas tendo em vista seus objetivos específicos. Embora, formalmente, o casamento na Roma antiga e o casamento cristão, por exemplo, sejam tão semelhantes que uma boa parte da lei romana sôbre a família poderia ser adotada por legisladores cristãos, seu conteúdo e propósito são muito diferentes devido à peculiaridade da concepção cristã da vida humana e do sexo. O grau de adeqüação destas concepções subjacentes determinará o valor histórico de uma dada instituição.

Além disso, os tipos de vida em comum permitem liberdade na escôlha da estrutura da organização que se lhes associa. Há, por exemplo, casos em que a família é co-extensiva com a comunidade religiosa, e o cabeça da família é ao mesmo tempo o sacerdote. Em outros casos a comunidade religiosa e a política são coextensivas, enquanto que em alguns países ou nações a separação entre Igreja e Estado, isto é, entre a comunidade religiosa e a política é considerada como vantagem para ambas. Anàlogamente, na sociedade primitiva a família atua como a guardiã da sabedoria e do conhecimento, verificando-se mais tarde uma diferenciação, vindo finalmente um sistema de educação mais ou menos autônomo ocupar o lugar do membro da família encarregado do ensino.

Estes tipos de vida em comum servem um duplo propósito. Ajudam, primeiramente, a enriquecer a vida. $O$ individuo torna-se capaz de aproveitar contìnuamente por êsse meio os dons específicos de outros indivíduos, e nesse intercâmbio não só o indivíduo mas o grupo como um todo se enriquecem. As contribuiçōes trazidas pelos vários tipos de vida em comum para a operação do cam- 
po histórico são tôdas igualmente importantes. O dito popular, por exemplo, de que a família é o fundamento do corpo político constitui uma formulação inadeqüada de valiosa verdade. E' certo que o estado sofre com a desintegração da vida familiar; mas seu bem-estar é também prejudicado quando, por exemplo, a vida religiosa declina ou a organização dos negócios funciona mal. 'Todos êstes tipos são igualmente essenciais para a vida histórica. Anàlogamente, porém, a exageração đe um dêles conduz a uma unilateralidade fatal no campo histórico. A êste respeito pouca diferença faz o tipo ao qual se atribui espeçial dignidade, seja êle a ordem econômica como no caso de Marx, ou a comunhão cultural como fazem os filósofos idealísticos, ou a Igreja na teoria católico-romana, ou a família quando louvada em prejuízo da vida pública segundo a moda de certos adeptos sentimentais do romanticismo.

Além de enriquecer o campo histórico e seus membros; êstes tipos de vida em comum constituem ao mesmo tempo o fator mais potente para conter as tendências anárquićas e anti-sociais de indivíduos e grupos, e assim aumentam consideràvelmente sua eficiência. Essa é a razão pela qual os grupos históricos se esforçam instintivamente em estimular a viđa nessas relações. Por outro lado é certo também que sempre que um ou outro dêsses tipos é desdenhado ou combatido, isto será em detrimento de todo o campo. Um estado, por exemplo, pode se aborrecer com o modo pelo qual uma comunidade religiosa tenta interferir na vida política. Mas, se a indignação justa se transforma no combate à igreja ou à religião, logo se torna manifesta a amplitude do mal que aquela nação está fazendo a si mesma por desacreditar o significado dos valores espirituais. O mesmo é verdade quando, por exemplo, em nome da livre iniciativa se tenta manter a vida econômica completamente isenta da supervisão dos poderes públicos, ou quando a família é reduzida à relações sexuais legalmente aprovadas, sendo suas demais funções delegadas à comunidade, como no estado ideal de Platão ou nos planos do primitivo bolchevismo.

iii). - Leis concernentes à Meta da História.

A meta da História nẳo é determinada pela natureza dos que agem històricamente, ou pelas circunstâncias específicas em que a História se dá. Antes, foi Deus quem the fixou a meta em seu eterno conselho. Assim a vida histórica apresenta certos traços que não se encontram em qualquer outra esfera da vida. Seu caráter teleológico virá inevitàvelmente à luz (lei da manifestação). Além disso, ao contrário da incessante repetição que caracteriza a vida or- 
gânica em outra esfera qualquer, um crescimento real até um estágio "perfeito" se verifica na História (lei do crescimento).
a)
. Lei da Manifestação.

Jesus revelou esta lei quando disse: "Nada está oculto, senão para ser manifesto; e nada foi escondido, senão para ser divulgado" (Marc. 4:22, cf. Luc 8:17, Mat. 10:26). A verdade dêste dito se encontra na pessoa de Jesus. Como o Filho do Homem êle revelou a tôdas as gerações o nivel de vida que a espécie humana devia finalmente atingir. E' certo que muitos perseguem seus próprios interêsses e não se preocupam com as conseqüências de suas ações para o bem-estar dos outros. Poder-se-ia, portanto, pensar que na História a humanidade simplesmente se reproduziu com um número infinito de variações, sem contudo passar jamais por uma radical mudança. Mediante a sociologia e a psicologia modernas, e sob forma popular mediante a novela moderna e o cinema, tal concepção tornou-se quase que um dogma indiscutivel. Todavia, ela é não só desafiada pelo idealismo e pelo humanismo, mas também na vida de Cristo se torna claro que o homem é capaz de vencer sua egocentricidade.

Na palavra acima Jesus não se referiu, porém, apenas à meta final da humanidade mas antes afirmou que tudo o que estivesse oculto seria revelado. Que significa esta afirmação criptica? Vivemos em um mundo submetido ao poder da delusão, e por isso a essência de uma coisa não pode ser inferida de sua aparência. Foi reconhecendo tal fato que tanto a filosofia como a ciência desenvolveram métodos críticos a fim de separar a verdade de meras opiniões. Uma pessoa, por exemplo, é capaz de esconder fàcilmente de outras seus motivos e o propósito de suas ações, e ela mesma pode até não perceber as fôrças propulsoras de sua vida. $O$ inconsciente desempenha um papel considerável em nossas ações. Isto é verdade especialmente na ação da massa e na vida coletiva. Daí provém a dificuldade que sentem as nações em compreender as ações de outras. O que aconteceu, por exemplo, com os alemães para levá-los a seguir Hitler, ou com os russos para aceitar o bolchevismo, ou com os japoneses quando se lançaram à conquista do Extremo Oriente? Sabemos que até os historiadores e estadistas mais hábeis explicarão quando muito alguns aspectos periféricos da vida de outras nações - o resto permanece como o grande e inquietante $x$ em tôdas as eqüações internacionais.

Anàlogamente, o significado de um momento histórico não é claro na ocasião em que êle ocorre e pode continuar obscuro por um tempo considerável. Foi só em 1930, por exemplo, que se começou a compreender as fatais implicações do tratado de Versalhes de 1919 para a vida internacional. Tal obscuridade oferece 
aos governos uma admirável oportunidade de impingir ao público sua versão de acontecimentos passados pela publicação de documentos escolhidos cuidadosamente. Temos um exemplo na Primeira Guerra Mundial cujas causas profundas ainda desconhecemos em boa parte, a despeito dos Livros Brancos e Azuis e de outras côres. Todavia, nem o poder de delusão nem o mêdo que o homem tem da verdade e nem sua distorção propagandística conseguem ocultar de modo permanente a verdade. O curso dos desenvolvimentos históricos escapa ao contrôle do homem. Assim, por mais que se esforcem as pessoas para esconder seus intentos de outras, virão situações que as forçarão a revelar seus motivos ou objetivos reais ou suas condições. A perda de uma vaso de guerra, por exemplo, pode ser oficialmente negada por algumas semanas, mas mesmo durante uma guerra um tal fato não pode ser mantido em segrêdo por meses ou anos. Anàlogamente, Hitler conseguiu disfarçar durante muito tempo a verdadeira natureza de sua política expansionista referindo-se a condições econômicas momentâneas. Mas quando êle obteve uma oportunidade de restabelecer os camponeses germânicos nos países bálticos e no Tirol do sul, o caráter imperialístico de sua política veio à luz .

Independentemente do fato que os motivos ocultos das ações históricas acabarão por se manifestar, a lei da manifestação se aplica a esfera mais ampla da vida histórica. E' teòricamente admissível pensar-se em um universo que fôsse sob todos os aspectos incompreensível ao homem. Exatamente como uma pessoa que observa um jôgo cujas regras desconhece nota movimentos para ela destituídos de sentido, assim também tôda a vida do homem pareceria em tais circunstâncias completamente sem significado. Na realidade, porém, êste é um mundo no qual a verdadeira natureza de tôdas as coisas se torna gradualmente evidente.

A verdade tem um poder tão grande na vida histórica porque ela implica um elemento objetivo. O homem é compelido pelo poder da verdade a aceitá-la finalmente, embora a tema ou the tenha aversão. Enquanto, por exemplo, não conhecemos ou não compreendemos a natureza do que nos cerca, sentimo-nos embaraçados ou vexados por sua estranheza, e assim, em lugar de agir segundo nossa melhor compreensão ou nossa natureza, tentamos nos ajustar ao pouco que conhecemos do mundo ao nosso redor e nos tornamos assim dependentes dêle. A verdade, entretanto, nos liberta. Quando penetramos o segrêdo dêste mundo ganhamos coragem de sermos nós mesmos e de vivermos nossa própria vida. Este efeito liberador, embora seja experimentado sobretudo nas manifestações de Deus na História da Salvação, encontra-se, todavia, em certo grau sempre que pela filosofia, pela ciência ou pela sabedoria alguém penetra os segredos dêste mundo. Ao mes- 
mo tempo, a verdade ao se manifestar age como um desafio sôbre os que a combateram ou tentaram suprimí-la, para que revelem seus motivos ou as razões de seu modo de agir. O desenvolvimento da igreja antiga no império romano, por exemplo, desmascarou o vazio dêste império que era encoberto por sua majestosa fachada. Igualmente, as reformas monásticas da Idade Média serviram para trazer à luz a fraqueza interna da organizaçã̉o oficial da igreja. Do mesmo modo, as muitas revoluções que açoitaram a Europa e as Américas nos últimos dois séculos mostraram a falsidade do retrato de felicidade idílica e de perfeição governamental que os regimes autocráticos ofereciam a seu respeito.

\section{b). - Lei do Crescimento.}

Conta-nos a história da criação que quando Deus criou o mundo orgânico e acima de tudo o homem "êle os abençoou e lhes disse: frutificai e multiplicai-vos, e enchei a terra: (Gên. 1:28). Quer interpretemos a narrativa como história ou como mito, esta sentença nos transmite uma profunda verdade. Não há nenhuma necessidade ontológica inerente à matéria que explique sua diferenciação em matéria orgânica e inorgânica. Podemos consistentemente imaginar um universo no qual tôdas as coisas tivessem exatamente a mesma aparência que agora têm, mas fôssem destituídas de vida. Na realidade, porém, êste é um mundo no qual as criaturas vivas não apenas mudam como também crescem por intrínseca necessidade, quer queiram quer não. Este fato é mais surpreendente ainda uma vez que não varia a quantidade de energia presente neste mundo. O crescimento não é um resultado da vontade do indivíduo. E' por esta razão que falamos de uma Lei do Crescimento. Essa lei não se confina aos indivíduos, aplica-se também a coletividades, e assim a campos históricos.

Nos tempos modernos tem-se interpretado a lei do crescimento como uma lei do progresso, como se houvesse um aperfeiçoamento necessário e inevitável das capacidades do homem e das condições em que êle vive e age. Esta concepção não é confirmada, porém, pelos fatos históricos. Excetuando-se a esfera em que Cristo reina, o aumento no processo de crescimento é apenas quantitativo. Mas uma vez que o homem, diferindo neste aspecto de todos os outros sêres, é capaz de aprender, encontramos na História uma gradual acumulação de descobertas, noções e habilidades e um aumento dêste acervo sempre crescente de instrumentos. Como resultado o homem expande gradual e constantemente seu domínio sôbre a natureza. A meta para a qual o homem avança na História em virtude da lei do crescimento é um estado de coisas em que tôdas as potencialidades do homem estarão rea. lizadas. Seria de esperar que êste desenvolvimento resultasse no 
aperfeiçoamento da condição do homem. Isto de fato se daria se não atuasse a lei da equalização de que trataremos adiante.

A lei do crescimento atua como uma incitação por detrás de tôda a vida histórica da humanidade. Mas embora ela contribua para o desenvolvimento de civilizações humanas, seu incitamento não é sempre e nem geralmente obedecido porque seus efeitos não se dão automàticamente. Antes êles estão condicionados ao esfôrço. Por isso indivíduos e grupos preferem muitas vêzes divertirse, gozando assim os frutos do trabalho passado. Como resultado não só a disposição como a capacidade de crescer diminuirão em certas secções da vida histórica. Mas esta estagnação longe de constituir um fenômeno normal é antes uma indicação de que o grupo está prestes a se desintegrar. Como se verá adiante, o crescimento não prossegue indefinidamente, mas cessa em um ponto determinado. Paradoxalmente, contudo, a humanidade como um todo não envelhece nem se desintegra. O Novo Testamento explica êsse estranho fenômeno. Ele decorre do fato de que a humanidade está destinada a crescer até à plena medida do Filho de Deus (Efes. 4:13).

Quer isto dizer que há ilimitadas possibilidades para o crescimento do gênero humano, porque o homem está destinado a transcender-se e, sendo embora um cidadão dêste mundo, a tornarse como Deus.

iv). - Leis concernentes ao Resultado da História.

Vamos discutir três leis que são particularmente importantes parả a consecução do resultado da História: as leis da eqüalização, da limitaçâo e do esquecimento.

\section{a). - Lei da Eqüalização.}

Esta lei foi antecipada pelo Pregador quando êle se lamentava de que "tudo é vaidade. Que proveito tem o homem de todo seu trabalho, com que se fadiga debaixo do sol? Uma geração vai e outra geração vem, mas a terra permanece para sempre" (Ecl. 1:2-4). Para nossa avaliação da História, a lei da eqüalização devia ocupar a posição suprema. Mas devido à disposição otimista de nossa época sua operação é geralmente ignorada. Esta lei afirma que a condição do homem na História não muda essencialmente através das idades, porque a razão entre as vantagens e os perigos permanece estacionária. Tudo neste mundo é ambivalente, pode ser e é usado para fins bons e maus, para propósitos construtivos como destrutivos. A tecnologia, por exemplo, aumentou imensamente nosso contrôle da natureza, mas também nossa ca- 
pacidade de causar danos e destruição. Igualmente, o automóvel torna a vida moderna confortável e faz-nos capazes de conquistar grandes extensões dos continentes. Mas êle mata e mutila mais gente no tempo de paz do que os canhões durante as guerras. Encontramos outro exemplo no desenvolvimento da vida econômica e tecnologia modernas que elevaram o nível de vida a um ponto que jamais podia ser previsto. Mas a intensidade de trabalho, a densidade de tráfego, o muito que exige de nosso tempo e energia, para tornar possível êste estupendo desenvolvimento, requerem contra-medidas extensas e custosas para coibir suas perversas conseqüências. Anàlogamente, se de um lado a medicina moderna prolongou nossa vida-provável e acresceu espantosamente nossas possibilidades de curar as doenças, de outro, o custo do tratamento médico e hospitalar aumentou tanto que uma séria enfermidade traz uma catástrofe econômica para uma família da classe média. Não há esfera da vida que se furte à constante manifestação da lei da eqüalização.

E' por esta razão que a idéia do progresso, quando entendida em um sentido de aperfeiçoamento, deve ser rejeitada. $O$ inegável crescimento que se processa na História não consegue tornar a vida mais feliz ou mais segura. Não há meio algum de deter a lei da eqüalização, porque é a natureza pecaminosa do homem a causadora do mau uso que êle faz de suas aptidões e das coisas boas dêste mundo. Sòmente quando e sòmente onde o pecado foi vencido mediante o poder de Cristo é que há esperança de uma modificação radical da situação do homem na História. Compreendendo que o acréscimo quantitativo não constitui por si mesmo uma garantia de melhores condições, muitos estão agora ansiosos por deter a expansão no nível ótimo em vez de no máximo. Mas nenhuma mudança real decorrerá enquanto se definir o ótimo como aquilo de que se tira o maior rendimento. A centralidade atribuída aos próprios interêsses implica desconsideração pelos interêsses de outros que estão empenhados na mesma emprêsa. A dissatisfação assim criada conduz à deterioração das relações humanas, e dêsse modo o desenvolvimento confirma a validade da lei da eqüalização.

\section{b). - Lei da Limitação.}

Limites bem definidos são marcados para a extensão do poder e das realizações de um grupo histórico. Jesus nos recorda êsse fato ao perguntar: "Qual de vós pode acrescentar um cúbito à sua estatura?" (Mat. 6:27). Exatamente como os indivíduos, também as unidades históricas têm sua medida marcada além da qual não podem crescer. O mundo em que vivemos possui um equilí- 
brio bem definido, e a despeito do fato de estar constantemente em movimento e de os campos históricos dentro dêle estarem sempre mudando sua estrutura interna e suas constelações, êste mundo nunca se desequilibra. Quando um fator em um campo histórico, ou a relação de um campo histórico com os demais atinge o ponto em que o equilíbrio sofreria sérias perturbações, a tensão intrínseca do campo reduz, inevitàvelmente e sem exceção, a tal ponto as dimensões ou o poder da entidade super-crescida que ela cessa de pôr em perigo o equilíbrio do todo.

Pode-se ver a operação dessa lei na esfera da expansão quantitativa, por exemplo, no crescimento dos impérios. Desde os tempos dos reis assírios o sonho dos conquistadores tem sido subjugar todos os outros reis e ser o senhor do mundo todo. Mas muito antes que atinjam tal objetivo surge uma constelação histórica que detém o conquistador e destroi seu império. Não obstante a incerteza e a imprevisibilidade do futuro uma coisa é certa, por exemplo, no presente conflito entre o imperialismo americano e o russo: nenhum dos dois acabará dominando tôda a terra. Se uma dessas potências fôsse vencida e aniquiilada as nações menores imediatamente se voltariam contra o colosso sobrevivente, aproveitarse-iam de sua fraqueza momentânea, e restringiriam seu poder. Olhando assim para as unidades históricas, a História nos apresenta quadros alternados de integração e desintegração. As dificuldades de governar um corpo histórico de um único centro começam logo a crescer em progressão geométrica com sua expansão geográfica. Também, quanto maior o país maior é o número de elementos homogêneos não assimilados em seu seio, que acabarão rebelando-se contra seu domínio, tentando formar novos grupos soberanos. A história recente do Império Britânico constitui um exemplo interessante dêsse fato. Pode-se também prever que nacionalidades rebeldes causarão algum dia sérias dificuldades para o Império Bolchevista.

Uma outra manifestação da lei da limitação encontra-se no fato de que todos os corpos históricos têm seu período de vida bem determinado, além do qual são incapazes de se manter em existência. Quaisquer tentativas de fixar exatamente sua vida-provável seriam fúteis; estas diferem tanto como entre os indivíduos. Mas isto não quer dizer que alguns dêles vão escapar de sua desintegração final. Não nos devemos iludir pelo fato de que o cenário da História não pode ser mudado. A Itália da Idade Média ou a Itália moderna não são idênticas com o Império Romano há muito desaparecido. E' igualmente impropriedade de linguagem falar-se em história do proletariado, como se existisse qualquer continuidade entre a mais baixa camada social do antigo Egito ou de Roma, 
de um lado, e da Alemanha ou da França modernas, de outro. Cada grupo histórico tem seu proletariado próprio.

Spengler e Toynbee lembraram à nossa época êste aspecto da lei da limitação, quando, desviados por uma noção falsa de evolução, gostávamos de pensar que o mundo ocidental e as nações que o integram perdurariam inalteradas e substancialmente livres de danos até o fim dos tempos. Interpretada superficialmente a morte das nações parece alterar o equilíbrio da vida histórica. Mas por detestável que seja o fim de uma unidade histórica, a graça de Deus é tão grande que a vida histórica não se torna sem sentido por isso. Uma vez que o homem tem que viver num mundo que é penosamente pequeno e em certo sentido superpovoado, a morte a despeito do dano que causa, abre ao mesmo tempo lugar para a vida mais nova. Os velhos, que não querem passar as rédeas do govêrno, devem morrer para que as novas geraçōes tenham sua oportunidade. A nação poderosa que mantém seus vizinhos sob seu domínio, está condenada a cair finalmente, porque de outro modo as outras não teriam possibilidade de trazer sua contribuição à História. As catástrofes hsitóricas devem ser explicadas do mesmo modo. A destruição de tantas igrejas florescentes, por exemplo, que foram varridas pelas tribos teutônicas e pelos árabes em tôda a volta do Mediterrâneo desde o fim do IV século até o fim do X, foi certamente o maior desastre que jamais se abateu sôbre o cristianismo. Todavia, em conseqüência disto as igrejas do norte da Europa tiveram que crescer independentemente, e puderam assim desenvolver seu próprio tipo de cristianismo. Dêsse modo diversos tipos de vida da igreja e de espiritualidade vieram a existir, enquanto que de outra forma o tipo mediterrâneo teria dominado todo o desenvolvimento da Igreja. Uma dura perda tornou-se dêsse modo, ao mesmo tempo, uma fonte de enriquecimento para a Igreja como um todo.

O único grupo histórico que está isento da lei da limitação é a Igreja de Cristo. A razão é óbvia. Por sua natureza ela trabalha pela harmonia e age respeitando o equilíbrio da História, não estando primàriamente empenhada na busca da expansão quantitativa à custa de outros. Assim a Igreja não precisa ser coibida como outros corpos históricos. Mas mesmo aqui a exceção só se aplica à Igreja como um todo, e não a nenhuma das igrejas organizadas. $\mathrm{Na}$ medida em que, por exemplo, elas lutam por riqueza material ou pelo domínio sôbre outras igrejas ou corpos seculares, as igrejas individuais também se desintegrarão como outro grupo secular qualquer. Porém, enquanto as demais religiōes surgem e finalmente desaparecem, haverá sempre uma Igreja cristã até o último dia. 
c). - Lei do Esquecimento.

A História se caracteriza pela continuidade tanto do processo em si como da lembrança do passado na mente dos que constituem um campo histórico. O passado é um elemento da História a que nãe se pode escapar. Portanto agimos na História ou em continuação deliberada de nosso passado ou em rebelião contra êle. Faz parte da grandeza do homem o fato de que êle pode recordar coisas que não experimentou pessoalmente. Nenhum animal é capaz disso. Porém o homem é itambém um ser que esquece. A consciência histórica muda constantemente de perspectiva, e em conseqüência parte das coisas do passado que originalmente ocupavam o centro da atenção passam para a periferia e, não mais sendo essenciais, são esquecidas. Seus efeitos podem continuar, mas ninguém mais sabe quem as produziu, nem quando nem onde o foram, porque passaram a constituir um traço indistinto do passado indiscernível. E' relativamente pequeno o número dos que sabem, por exemplo, dos grandes feitos dos antigos babilônios, egípcios, gregos e romanos, e do período "pré-histórico" do homem, que foi indefinidamente mais longo que os $\mathbf{5 . 0 0 0}$ ou 6.000 anos de que temos registros históricos, mesmo os historiadores experimentados não têm senão vagas idéias. Acontecimentos que no seu tempo devem ter sido importantes revoluções como, por exemplo, a invenção do uso dos metais, da roda ou do tear, nos são conhecidos apenas através de seus efeitos.

São duas as principais razões do esquecimento. Uma é que a História produz constantemente novas coisas e novos acontecimentos, enquanto que a mente humana é capaz de lembrar sòmente um número limitado dêles. A outra é que as coisas passadas vão perdendo sua importância pela distância histórica, e ràpidamente. Quão poucas são as coisas que constituiram títulos de jornal há um ano atrás e que ainda merecem ser lembradas! Há na História uma necessidade intrínseca que faz o homem esquecer as coisas, embora por natureza êle seja um ser que quer lembrar o passado. Finalmente tudo o que resta do passado é o conhecimento que o homem tem dos indícios e não mais dos acontécimentos e de seus autores. O arqueólogo pode desenterrar tôda a sorte de implementos da história antiga, porém êles não the contam em que ocasião foram trazidos para a localidade de que são desenterrados, ou em quais circunstâncias, para que fins e por quem foram usados.

A lei do esquecimento é um jugo humilhante. Os que trabalham na História geralmente anceiam por reconhecimento e por renome. Mas as gerações subseqüentes estão a tal ponto preocupadas com seus problemas que demonstram pouco reconhecimento pela contribuição da precedente para o campo histórico. Simbòli- 
camente, e inúmeras vêzes literalmente, os jovens "heróis" de guerra tem que mendigar na velhice.

O esquecimento é um destino inevitável não obstante os esforços dos historiadores de contrariá-lo. A atividade histórica assenta-se nas realizações do passado, uma vez que elas estão incorporadas em instituições, leis, condições e implementos econômicos e culturais, por exemplo, instrumentos, obras de arte e de saber. Mas a vida histórica requer do homem tanto esfôrço para a construção do futuro que sobra pouco tempo e energia para lembrar com muitos pormenores como foram lançados os alicerces de nossa própria atividade histórica. Isto explica porque tão raramente as nações aprendem as lições do passado. Não é verdade que o passado nada tem para ensinar. Parece antes que nos defrontamos com a alternativa de ou empenharmo-nos em aprender a lição do passado e nada mais, ou experimentar ao acaso e agir sem direta orientação do passado. Esta alternativa explica porque as nações são tão pouco inclinadas a receber ensinos do passado.

Uma vez esquecida uma coisa do passado, é pràticamente innpossível trazê-la novạmente à lembrança. A magia, as religiões de mistério e a pesquisa psíquica tem sido utilizados para trazê-las de volta. Mas diferindo da história viva o passado tende a tornarse uma massa indiscriminável que determina as atividades dos vivos em sua totalidade contudo sem pormenores discerníveis. O historiador sabe muito bem que o conhecimento dos registros do passado não eqüivale a lembrar. $O$ fato passado permanece incompreensível e inexplicável quando desligado das memórias vivas. Estritamente falando, portanto, a esfera das reminiscências históricas limita-se ao campo histórico a que cada um pertence.

A operação da lei do esquecimento, penosa e humilhante como é para o homem, serve, entretanto, um propósito definido de Deus. O homem tem uma forte tendência de se atribuir todo o crédito pelas realizações históricas. O fato que finalmente mesmo os maiores homens da História serão esquecidos lembra-nos da falsidade implícita na estima em que nos temos. Se há qualquer significado objetivo na História, êle decorre do contrôle de Deus sôbre a História e não de feitos humanos. A grandeza histórica não é senão um têrmo relativo. E' relativo a uma dada situação e aos contemporâneos daqueles a que o têrmo se aplica e mede-se por comparação com o que foi realizado em outros campos. O pensamento de que por grandes que sejam os louvores dos contemporâneos de alguém, seu nome em breve será esquecido, tende a nos dar a justa perspectiva para a avaliação de nossa importância.

(Continua no próximo número). 